\title{
A Study of Noncovalent Complexes Involving Single-Stranded DNA and Polybasic Compounds Using Nanospray Mass Spectrometry
}

\author{
Peran Terrier, Jeanine Tortajada, and William Buchmann \\ Laboratoire Analyse et Modélisation pour la Biologie et l'Environnement, Université d'Evry-Val d'Essonne, \\ CNRS UMR 8587, Evry, France
}

\begin{abstract}
Noncovalent complexes involving a single-stranded DNA oligonucleotide and a polybasic compound (spermine, penta-L-lysine, penta-L-arginine, or polydisperse poly-L-lysine) were detected by nanospray-MS. Several control experiments tended to show that these complexes preexisted in solution and that the interactions were initially ionic ones between oligonucleotide phosphates and protonated basic sites of the polybasic compound. Collision-induced dissociation (CID) experiments carried out with these complexes allowed us to identify some differences in the nature of the interactions between the solution and the gas phase, arising from possible proton transfers. Different dissociation pathways were observed according to the nature of the polybasic compound and to the initial charge state of the complex. The complex involving spermine dissociated by cleavage of noncovalent bonds leading to the separation of the two components, whereas the one involving penta-L-arginine underwent fragmentations of covalent bonds. Both behaviors were independent of the initial charge state of the complex. On the other hand, the dissociation pathway of the complex involving penta-L-lysine has been shown to be clearly charge state dependent. Noncovalent dissociation (separation of the two components) driven by coulomb repulsion occurred for the higher charged complexes, whereas fragmentation of covalent bonds was the main pathway of the lower charged complexes. In the latter case, differences in CID behavior were observed for different lengths of poly-L-lysine. (J Am Soc Mass Spectrom 2007, 18, 346-358) (c) 2007 American Society for Mass Spectrometry
\end{abstract}

$\mathrm{I}$ n living organisms, DNA phosphates bear negative charges and can interact with cationic molecules through ionic bonds. Such bonds involving protonated basic amino acid residues [Lysine (Lys), Arginine (Arg), and Histidine (His)] play an important role in DNA-protein interactions. An example is the packaging of DNA in cell nuclei by histones, which are proteins including a high proportion of basic residues [1]. Moreover, some natural polyamines such as putrescine $\left(\mathrm{NH}_{2}-\mathrm{C}_{2} \mathrm{H}_{8}-\mathrm{NH}_{2}\right)$, spermidine $\left(\mathrm{NH}_{2}-\right.$ $\left.\mathrm{C}_{3} \mathrm{H}_{6}-\mathrm{NH}-\mathrm{C}_{4} \mathrm{H}_{8}-\mathrm{NH}_{2}\right)$, and spermine $\left(\mathrm{NH}_{2}-\right.$ $\mathrm{C}_{3} \mathrm{H}_{6}-\mathrm{NH}-\mathrm{C}_{4} \mathrm{H}_{8}-\mathrm{NH}-\mathrm{C}_{3} \mathrm{H}_{6}-\mathrm{NH}_{2}$ ) are present in cells as multi-protonated molecules and can interact with DNA [2]. Furthermore, complexes involving polybasic compounds and DNA have attracted new interest as a way to transport a therapeutic gene or an oligonucleotide in a cell. Poly-L-Lysine, polyamines, and their derivatives are extensively studied vectors [3, 4].

Published online November 7, 2006

Address reprint requests to Dr. William Buchmann, Laboratoire Analyse et Modélisation pour la Biologie et 1'Environnement, Université d'Evry-Val d'Essonne, CNRS UMR 8587, Bât. Maupertuis, Bd. F. Mitterrand, 91025 Evry cédex, France. E-mail: william.buchmann@univ-evry.fr
The development of electrospray ionization (ESI) [5] and matrix-assisted laser desorption/ionization (MALDI) [6, 7] allowed the emergence and rapid growth of the mass spectrometry of noncovalent complexes [8-11]. Complexes involving DNA are considerably less studied than those involving proteins and studies of the attachment between DNA and polyamines or polybasic peptides are particularly scarce. The only observations of natural polyamineoligonucleotide complexes by mass spectrometry have been reported in the case where spermine was used as matrix additives for oligonucleotide analysis by MALDITOF [12-15]. In this case, protonated sites of the polyamine were expected to bond DNA phosphate in solution to displace alkaline cations [12-14] and stabilize duplexes [15]. Ideally, polyamine protons were transferred to DNA phosphates during sample crystallization or desorption/ ionization process and the oligonucleotide free of alkaline cation and polyamine was observed. However, under some matrix conditions, unwanted polyamine-oligonucleotide complexes were detected.

Furthermore, polybasic peptide-oligonucleotide complexes have also been detected by MALDI-TOF 
[16â21].âObservationâofâsuchâcomplexesâwasâfirstâre-

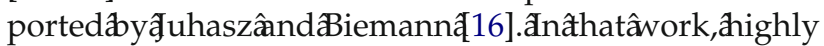
acidic compounds (such as DNA) were detected as noncovalent complexes with a peptide or a small protein rich in Arginine, Lysine, and/or Histidine. Subsequently,âVertesâetâal.â[17]âstudiedâinteractionsâbetween single-stranded oligonucleotide and basic dipeptides or smallâproteins.âWoodsâetâal.â[18]âformedâcomplexes between basic peptides with various sequences and single/double-stranded oligonucleotides. By varying $\mathrm{pH}$ and comparing theoretical protonation state of free oligonucleotide nucleobases and phosphates with the presence or absence of complexes, interactions have been proven to occur between oligonucleotide phosphatesâandâpeptideâbasicâresiduesâandâtoâbeâionicâ[17, 18].âAnotherâvidenceâofâtheânatureâfâtheseânteractions was the observation of a competition between basic peptides and alkaline cations to bind the oligonucleotide phosphates: peaks of oligonucleotide-peptide complexes were sharper than those of free oligonucleotide, indicating a displacement of alkaline cations by basic peptidesâ [17].â Conversely,â whenâ increasingâ ionic strength (by increasing ammonium salt concentration), ammonium cations displace basic peptides, resulting in the disappearance of the complex in the mass spectrum [18].âlnâsomeâcases,âvariousâstoichiometriesâhaveâbeen observed, suggesting the absence of a specific binding site.

Byâusingâdifferentâoligonucleotides,aWoodsâtâl.ẫ18] confirmed that, at neutral $\mathrm{pH}$, oligonucleotide base sequence does not seem to have any influence on the formation of the complex, whereas the composition of the peptide is important. First, the efficiency of complex formation depends obviously on the presence and numberâofâbasicâresiduesâinâtheâpeptideâ[17].âlnterestingly, Arginine seems to have a greater role in the complex formationâthanâLysineâandâHistidineâ[17].âThisâcanâbe explained by a greater stability of its bond with the phosphate group in solution or in the gas phase resulting from its structure. Furthermore, the proportion and the arrangement of the basic amino acids within the peptide have been found to be important. Indeed, Woodsâ etâ al.â [18]â observedâ thatâ atâ leastâ fiveâ basic residues in close proximity to each other, but separated by aliphatic residues, seemed to favor the formation of a complex with an oligonucleotide. This suggests that the geometry of the complex can play a role and/or that forces other than ionic ones are involved. Vasseur et al. [19]âusedâMALDI-TOFâtoâobserveâcomplexesâbetween single-stranded oligonucleotide and guanidine derivatives (guanidine being the basic site of the arginine residues). They showed that the presence of an aromatic ring permitted a better interaction, pointing out the importance of complementary hydrophobic forces and $\pi$-stacking. Such a peptide-sequence dependency has beenâobservedâbyâWoodsâetâal.â[20]âinâtheâcaseâofâthe "helix clamp" motif of HIV-1 reverse transcriptase. Although the interaction was not dependent on the oligonucleotide sequence, a precise arrangement of basic residues was needed to make the attachment possible.âFinally,âLiâetâal.â[21]âreportedâtheâobservation by MALDI-TOF of a basic peptide-oligonucleotide complex where interaction was clearly dependent on the oligonucleotide sequence.

Even though ESI is the most often used ionization technique for noncovalent complexes studies, it has rarely been used to observe polybasic compoundoligonucleotide complexes. However, some complexes involving peptides held together by acid/base interactions have been studied by ESI-MS and tandem mass spectraâ(ESI-MS/MS).âSchugâandâLindnerâ[22,â23]âassessed the potential of ESI to carry out titration and competition experiments with complexes involving acidic and basic amino acids (and their derivatives). They indicated the large differences of transfer coefficient (from solution to gas phase) between complexes that differ by the nature of one component. This difference renders quantitative ESI-MS studies very difficult because the intensity of complexes depends not only on their initial concentrations, but also on the aforementioned transfer coefficients. On the other hand, they showed that MS/MS, and particularly dissociation curves (in which the extent of the complex dissociation is measured as a function of the collision energy), permitted a comparison of the gas-phase stability of different complexes.

Complexes between basic and acidic peptides have also been studied. After the detection by MALDI-TOF of complexes between a peptide including an Arg-rich pattern [(Arg $)_{2-5}$, Arg-Lys-Arg, or (Arg) $)_{4}$ - LysArg] and a peptide including two to five Aspartic/ Glutamicâacidâresiduesâ[24,â25]âorâoneâphosphorylated residueẫ 24,â26],âWoodsâtâl.ẫ 27-29]âusedâtandemâmass spectrometry to assess gas-phase stability of such complexes. Dissociation curves showed that binding of six adjacent basic residues with one phosphorylated residue was comparable to the one with a $(\mathrm{Glu})_{5}$ pattern [29].âTheâ greatâstabilityâ ofâtheâinteractionsâbetween phosphate groups and basic residues was confirmed by the fact that cleavage of noncovalent bonds is not the only collision-induced dissociation (CID) pathway: covalent cleavage within the acidic peptides leading to the transfer of the phosphate group to the basic peptide was alsoâpreviouslyâobservedâ[28].

The present work focuses on interactions occurring between a single-stranded DNA oligonucleotide and a simple polybasic compound (spermine, penta-L-lysine, penta-L-arginine, or poly-L-lysine). In solution, these interactions are supposed to be ionic between oligonucleotide phosphates and basic sites of polyamine or peptide. One aim of this study was to better understand the behavior of ionic bonds during the transfer from solution to gas phase, which would facilitate mass spectrometry studies of more complicated systems. Beyond its fundamental interest, however, this study deals with models of DNA polyplexes that are of great interest for gene therapy. They involve polydisperse polymers bound to DNA by nonspecific interactions. It 
is noteworthy that, in this case, nonspecific interactions are far from uninteresting or insignificant interactions. Within this context, mass spectrometry can make its contribution as a method permitting an accurate analysis of (stoichiometry- and component size-) heterogeneous mixtures.

In this study, we show that nanospray-MS allows the observation of complexes involving a single-stranded oligonucleotide and polybasic compounds such as not only penta-L-arginine (as already described for MALDI-MSâ[16â21,â24â26]âorâESI-MSâ[22,â23,â27-29] with related systems) but also spermine, penta-L-lysine, and polydisperse poly-L-lysine. ESI-MS/MS was used to explore the interactions taking place in these complexes in the gas phase. Because several studies showed that the dissociation pathways of oligonucleotide duplexes or oligonucleotide-drugs complexes are dependent on their initial charge state and that the presence of a charge on the ligand can influence their stability [30â33], âweâpaidâparticularâattentionâtoâtheâinfluenceâof the charges borne by the complexes. Different dissociation pathways will be described and discussed according to the charge state of the complex, and the nature and length of the polybasic compound.

\section{Experimental}

The single-stranded 12-mer oligodeoxyribonucleotide 5'-ACTGGCGCGACA-3' $(\mathrm{M}=3655.4 \mathrm{Da})$ and the penta-L-arginine $(\mathrm{M}=798.9 \mathrm{Da})$ were purchased from Eurogentec (Seraing, Belgium). Ammonium acetate, penta-L-lysine $(\mathrm{M}=658.9 \mathrm{Da})$, penta-L-alanine $(\mathrm{M}=$ 373.4 Da), spermine $(\mathrm{M}=202.3 \mathrm{Da})$, and poly-L-lysine $(\mathrm{M}=1000-4000 \mathrm{Da})$ were purchased from SigmaAldrich (Lyon, France). Oligodeoxyribonucleotide and polybasic compounds were used as received. Generally, equimolar solutions containing $60 \mu \mathrm{M}$ oligonucleotide and polybasic compound were prepared in $10 \mathrm{mM}$ aqueous ammonium acetate $(\mathrm{pH}=6.5)$. The solutions were kept at $40{ }^{\circ} \mathrm{C}$ for $15 \mathrm{~min}$ and allowed to cool to room temperature before analysis.

All experiments were carried out using a Q-Star Pulsar quadrupole-TOF mass spectrometer (Applied Biosystems, Foster City, CA) equipped with a Protana nanospray ionization source (nanoES) operating in the negative ionization mode. Capillary voltage was -800 $\mathrm{V}$. Declustering potential 1 (DP1) was generally $-40 \mathrm{~V}$; focusing potential (FP) was $-220 \mathrm{~V}$; declustering potential 2 (DP2) was - $15 \mathrm{~V}$. In MS/MS mode, the quadrupole was operating with unit resolution. $\mathrm{N}_{2}$ was used as collision gas with a 3 psi pressure. Collision voltages were varied between -5 and $-70 \mathrm{~V}$. When a quadrupole was operating in the RF-only mode, its settings were adjusted to obtain a homogeneous transmission of the ions from the ion source to the TOF analyzer, over the entire mass range.

BreakdownâgraphsâwereâmadeâfromâCIDâspectra recorded at several collision voltages. They represent the relative areas of the intact complex and of the different kinds of product ion as a function of the translational energy of the complex (product of its charge state and collision voltage). Translational energy was preferred to collision energy to be able to compare values from complexes having different charge states. Relative area is the peak area divided by the sum of the areas of all spectrum peaks. Because some points correspond to the sum of minor ions, there may be an error of $5 \%$ intensity according to the chosen threshold.

\section{Results and Discussion}

\section{Mass Spectrometry Detection of the Noncovalent Complexes}

The first part of this study describes the detection by nanoES-TOF of noncovalent complexes involving an oligonucleotide and a polybasic compound. Because the complexes were expected to be negatively charged in solution, all spectra were recorded in the negative ion mode.âFigureâla-ââ̂showâspectraâofâaqueousâmixtures involving the oligonucleotide (5'-ACTGGCGCGACA$3^{\prime}$, noted Oligo) and, respectively, spermine (noted sp), penta-L-lysine (K5), and penta-L-arginine (R5). An ammonium acetate buffer was present in all mixtures. In each case, free single-stranded Oligo carrying three to eight negative charges (deprotonations) was abundantly detected. Moreover, fivefold-charged Oligo dimer $\left[\left(\mathrm{Oligo}_{2}\right)^{5-}\right]$ was detected with low abundance in allâspectra.âFreeâspermineâwasânotâobservedâ(Figureâla) and the intensity of free penta-L-arginine was extremelyâweakâ(Figureâ1c).âOnâ theâ otherâ hand,â free deprotonated penta-L-lysine $\left(\mathrm{K}^{-}\right)$was abundantly detectedâ(Figureâlb).âTheâpresenceâofââterminalâcarboxylic acid in K5 (its only acidic site) explains its deprotonation. Because spermine has no acidic site, its absence in the negative mode was expected. The near absence of negatively charged R5 was more surprising because this component includes a terminal carboxylic acid (like K5) and can be detected as a deprotonated species when Oligo is not present in the mixture. Actually, this may be attributable to the noncovalent intramolecular bond between carboxylic acid and one of the arginine residues.âlndeed,âSchugâandâLindnerâ[23]âshowedâthatâthe interaction between the basic group of arginine and a carboxylate group was very stable in the gas phase. Because these two chemical groups have a fork shape, the authors supposed this stability was partly a result of their complementary geometries. Such an interaction within R5 could make its deprotonation more difficult, thus potentially preventing its detection in the negative mode in the presence of oligonucleotide. Finally, several noncovalent complexes involving oligonucleotide(s) and polybasic compound(s) were observed in each case. Like the noncovalent oligonucleotide dimer,

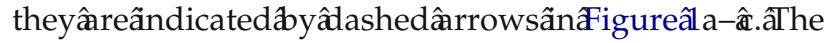
most abundant complexes had a 1:1 (Oligo:polybasic compound) stoichiometry and were present with various charge states (framed labels). Complexes involving 
(a)
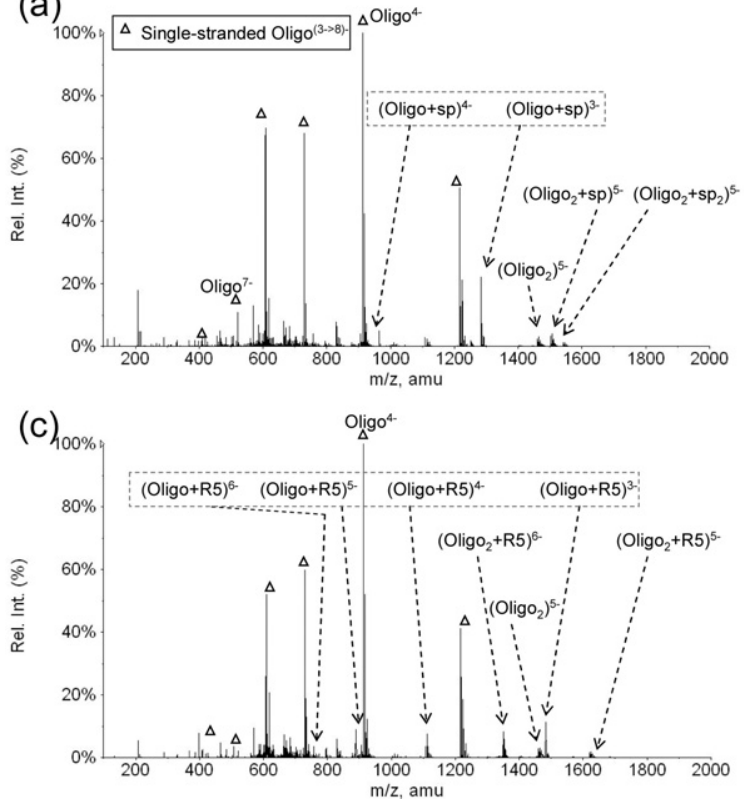

(b)
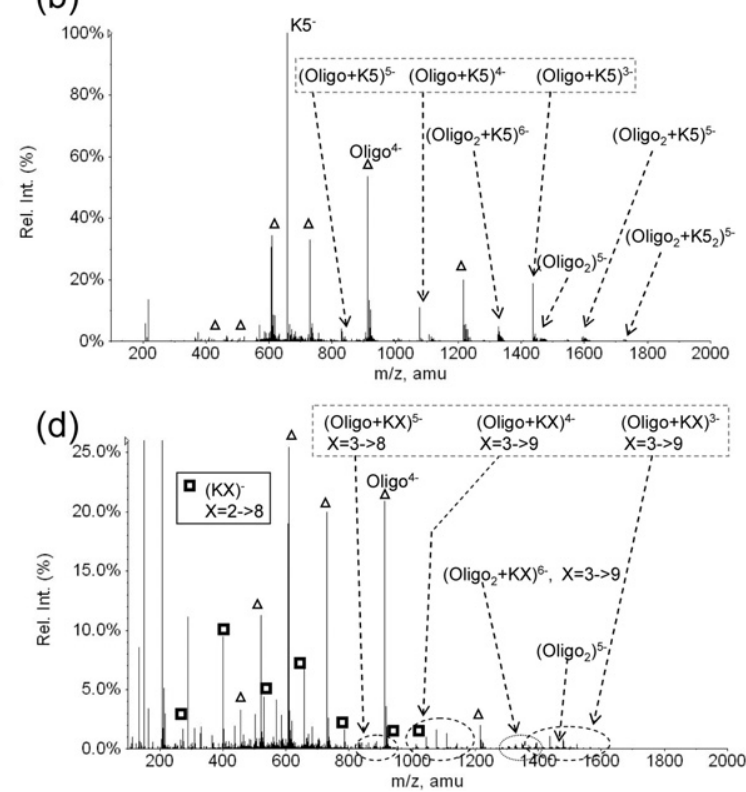

Figure 1. nanoES-MS spectra of the oligonucleotide 5'-ACTGGCGCGACA-3' (noted Oligo. in the presence of (a) spermine (sp), (b) penta-L-lysine (K5), (c) penta-L-arginine (R5), (d) poly-L-lysine (KX). $[$ Oligo $]=[\mathrm{sp}]=[\mathrm{K} 5]=[\mathrm{R} 5]=60 \mu \mathrm{M}$, [poly-L-lysine $]=60 \mu \mathrm{g} \mathrm{mL}^{-1},\left[\mathrm{CH}_{3} \mathrm{COONH}_{4}\right]=10 \mathrm{mM}$. Noncovalent complexes are indicated with dashed arrows and all charge states of a same stoichiometry are at the same level. Labels of complexes with 1:1 stoichiometry are framed.

two oligonucleotides and one or two polybasic compounds were observed as well.

Figureâl dâshowsâtheâmassâspectrumârecordedâfromâa mixture of Oligo and polydisperse poly-L-lysine (KX) in the presence of ammonium acetate. As with $\mathrm{K} 5$, free Oligo and free polybasic compounds (singly charged, with two to eight lysine residues) were detected. Oligo dimer, 1:1 and 2:1 (Oligo:KX) complexes involving poly-L-lysine with three to nine lysine residues, were also observed with various charge states. Complex intensities were lower than those with monodisperse penta-L-lysine, arising from signal dilution over several peaks.

Given that formation of aggregates in the gas phase during the ESI process is a well-known phenomenon, it is important to consider the origin of the observed noncovalent complexes: do they preexist in solution or are they formed in gas phase? To probe the origin of the intense 1:1 complexes, three control experiments were carried out. First, a spectrum of a solution including Oligo and penta-L-alanine was recorded under the same experimental and instrumental conditions as those used for the recording of the spectra shown in Figureâ1.âUnlikeâpenta-L-lysineâandâpenta-L-arginine, penta-L-alanine has no basic residue; thus, no complex is expected to preexist in solution. The nanoES-TOF spectrum showed free oligonucleotide and free pentaL-alanineâbutâabsolutelyânoâcomplexâ(Figureâ2a).âThis indicated that the presence of basic sites on the peptide is necessary for the observation of a noncovalent com-
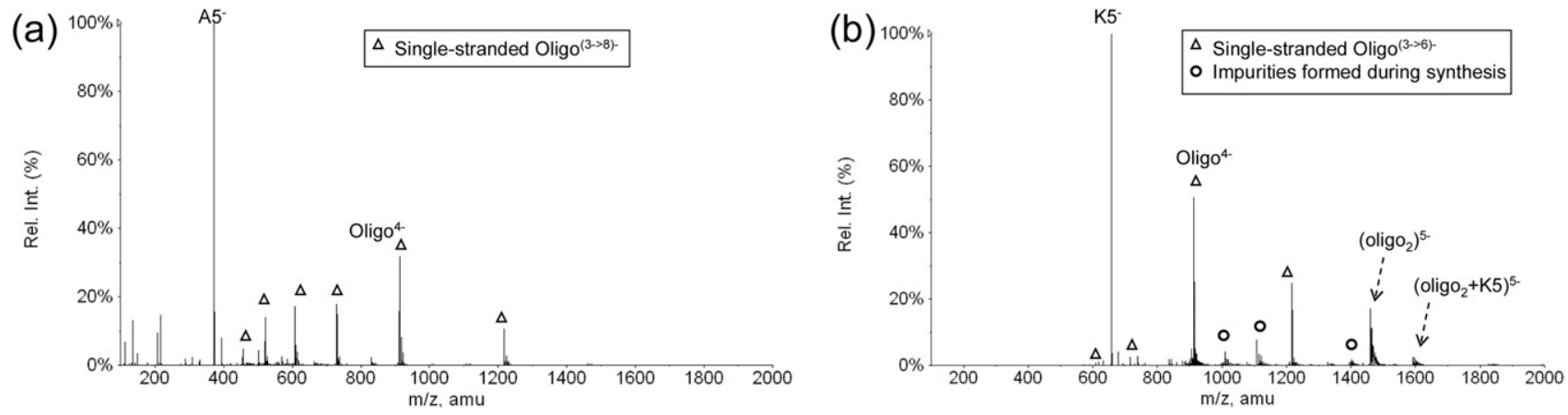

Figure 2. nanoES-MS spectra of the oligonucleotide 5'-ACTGGCGCGACA-3' (noted Oligo) in the presence of (a) penta-L-alanine (A5), (b) penta-L-lysine (K5) with an ammonium acetate concentration

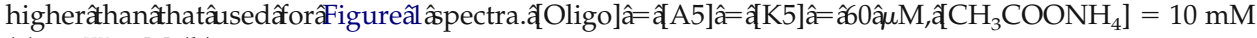
(a) or $75 \mathrm{mM}(\mathbf{b})$. 
plex, as in solution. Then, spectra of (Oligo+K5) were recorded with different ionic strengths. A typical solution consisted of $60 \mu \mathrm{M}$ of each component in $10 \mathrm{mM}$ ammoniumâacetateâ(Figureâ1a).âFigureâ2bâshowsâthe spectrum obtained when the ammonium acetate concentration was increased to $75 \mathrm{mM}$. Free Oligo and free K5 were observed, but no (1:1) complexes. Only a small amount of (2:1) (Oligo:K5) complex survived. This resultâsuggestsâthatâtheâcomplexesâobservedâinâFigureâl preexisted in solution and that the interactions were initially ionic. Indeed, in solution, ammonium ions (from ammonium acetate buffer) compete with protonated lysine residues to bind to oligonucleotide phosphates. When the number of ammonium ions is increased, ammonium-phosphate interactions are favored and the complex is dissociated. No spectra were recorded with a higher ammonium concentration because it leads to an unstable spray. Upon decreasing the ammonium acetate concentration from 10 to $0 \mathrm{mM}$ (data not shown), intense complexes were still observed, although the charge states were dramatically modified. Thus, the relative intensity of the complex is no longer comparable with that of $10 \mathrm{mM}$ ammonium acetate solutions. Finally, it is known that a too high concentration of analyte can favor gas-phase aggregation. Therefore, concentrations of Oligo and $\mathrm{K} 5$ were decreased from 60 to $20 \mu \mathrm{M}$ then $10 \mu \mathrm{M}$, with constant ammonium acetate concentration $(10 \mathrm{mM})$ (data not shown). Complexes were still observed in each case, suggesting again that they were formed in solution rather than in the gas phase. However, the relative abundances of Oligo, K5, and complex changed with the decrease in analyte concentration. This change can be attributed to the difference in response as a function of concentration for each species.

The origin of the other noncovalent complexes was also considered. It should be noted that Oligo does not have a self-complementary sequence, so its observation as a dimer was not expected. However, this dimer can in fact exist in a small amount in solution because 6 of the 12 bases can autoassociate by Watson-Crick bonds. Therefore, the gas-phase dimer may come from solution. This supposition is confirmed by the fact that the intensity of the oligonucleotide dimer increases with the ammoniumâacetateâconcentrationâ(seeâFigureâ2b).âIndeed, the higher the ionic strength, the more shielded the negatively charged oligonucleotide phosphates and the more favorable the oligonucleotide autoassociation in solution. The preexistence of such a dimer in solution would explain the presence of complexes involving one polybasic compound and two oligonucleotide:polybasic compounds would bind an oligonucleotide dimer rather than two free oligonucleotides. Indeed, basic sites of polybasic compounds are clearly less numerous than acidic sites of the oligonucleotide. Therefore, a $\left(\mathrm{Oligo}_{2}+\right.$ polybasic compound) complex involving ionic bonds only seems to be far less probable than a complex in which an Oligo dimer bound by Watson-Crick bonds interacts with the polybasic compound by ionic bonds.
In summary, complexes between an oligonucleotide and a polybasic compound can be detected by nanoESMS. Although it was suggested that these complexes preexisted in solution, no quantitative study in nanoES-MS mode (such as $\mathrm{K}_{\mathrm{D}}$ determination) was attempted. Indeed, because of structural differences, transfer coefficients of free oligonucleotide, free polybasic compounds, and corresponding complexes are probablyâveryâdifferentâ[22,â23].âMoreover,âtheâproportions of observed free components directly coming from the solution and coming from gas-phase decomposition of the complex are not known. These features prevent the carrying out of titration or competition experiments [10].âOnâtheâotherâhand,ânanoES-MS/MSâstudiesâwere carried out to probe the gas-phase stabilities of the complexes. It was particularly interesting to explore the phosphate group-amine interaction in the gas phase as a function of the nature of the polybasic compound and to probe the influence of charge state of a complex on its stability.

\section{Tandem Mass Spectrometry: Influence of the Nature of the Polybasic Compound and Charge State}

CID experiments were carried out first on free Oligo, then on (Oligo $+\mathrm{sp}),(\mathrm{Oligo}+\mathrm{K} 5)$, and (Oligo $+\mathrm{R} 5) \mathrm{com}-$ plexes. In each case five-, four-, and threefold-charged ion were studied. CID spectra were systematically recorded at several translational energies up to the energy required to totally dissociate the precursor.

CID products of free Oligo were intact phosphodiester backbones having lost a neutral nucleobase and $\mathrm{a}-\mathrm{B} / \mathrm{w}$ sequence ions (according to the McLuckey nomenclatureâ[34]).âWhateverâtheâchargeâstateâofâOligo (five, four, or three negative charges), a-B and w ions covered the entire sequence, provided that translational energy was low enough. An increase of the translational energy logically led to the observation of lighter $a-B / w$ ions (including some internal fragments). As an example,âhistogramsâinâFigureâ3âdisplayâtheâabundanceâof each $\mathrm{a}-\mathrm{B}$ and $\mathrm{w}$ ions produced by CID of Oligo ${ }^{3-}$ as a function of their length and charge state, at three different translational energies.

Figureâ 4a-âdâ displayâ examplesâ ofâ CIDâ spectra for $(\mathrm{Oligo}+\mathrm{sp})^{4-},(\mathrm{Oligo}+\mathrm{K} 5)^{4-},(\mathrm{Oligo}+\mathrm{K} 5)^{3-}$, and $(\mathrm{Oligo}+\mathrm{R} 5)^{4-}$, respectively. These spectra were recorded with a translational energy for which the precursor ion has an area equal to roughly $50 \%$ of the total ion current, allowing their comparison. A more global comparison can be made thanks to the breakdown graphsâdisplayedâinâFigureấa-đn.

Spermine. In the CID spectrum of $(\mathrm{Oligo}+\mathrm{sp})^{4-}$ recordedâatâ60âeVâtranslationalâenergyâ(Figureâ4a),âthe main product ion was Oligo ${ }^{4-}$. This ion was produced by noncovalent dissociation of the complex, leading to the loss of neutral spermine. Because in-solution inter- 

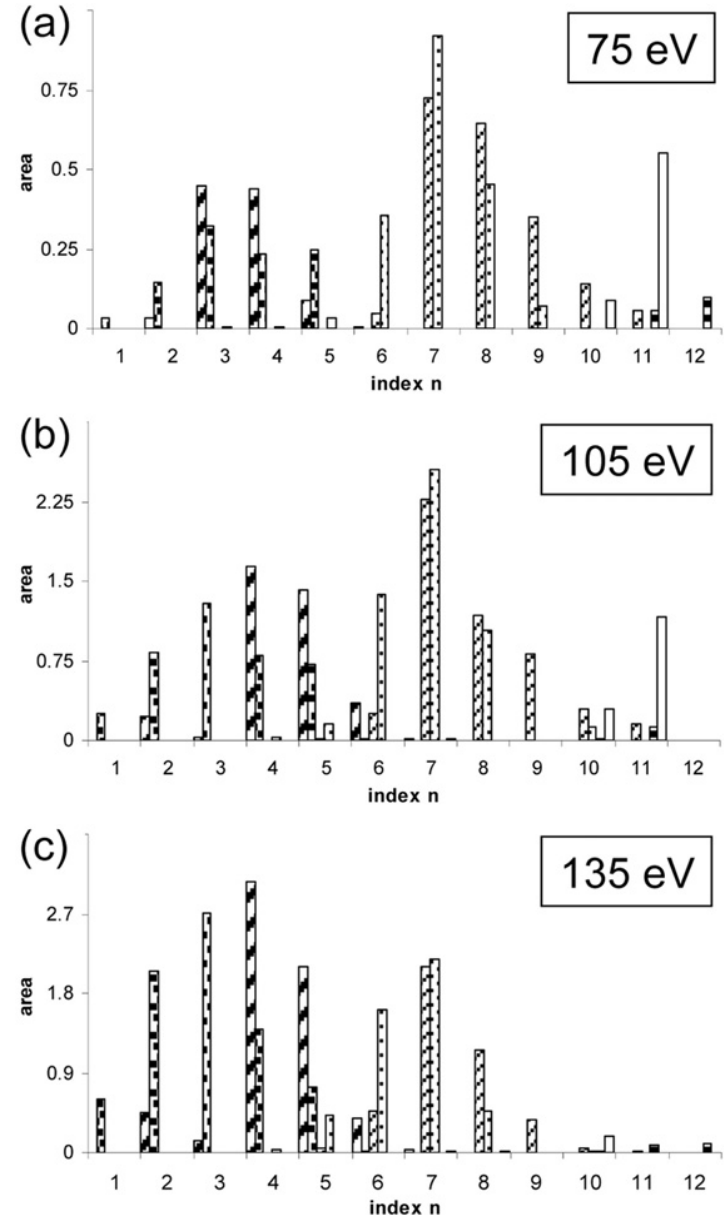

$$
\begin{array}{ll}
\square a_{n}-B \text { with } 1 \text { charge } & \text { a } w_{n} \text { with } 1 \text { charge } \\
\square a_{n}-B \text { with } 2 \text { charges } & \quad \text { own with } 2 \text { charges } \\
\Xi a_{n}-B \text { with } 3 \text { charges } & \square w_{n} \text { with } 3 \text { charges }
\end{array}
$$

Figure 3. Abundances of the $a-B / w$ ions produced by $C I D$ of Oligo $^{3-}$ as a function of their length and charge state. Translational energy is $75 \mathrm{eV}(\mathbf{a}), 105 \mathrm{eV}(\mathbf{b}), 135 \mathrm{eV}$ (c). Internal fragments are not shown.

actions are ionic ones between protonated basic sites of spermine and negatively charged oligonucleotide phosphates, proton transfers occurred from spermine to oligonucleotide $\left(\mathrm{R}_{2} \mathrm{NH}_{2}^{+},{ }^{-} \mathrm{O}-\mathrm{PO}_{3} \mathrm{R}_{2} \rightarrow \mathrm{R}_{2} \mathrm{NH}+\right.$ $\mathrm{HO}-\mathrm{PO}_{3} \mathrm{R}_{2}$ ). Two hypotheses can be envisaged concerning the moment at which the protons are transferred. In the first hypothesis, the phosphate-amine interactions in the gas phase remained ionic (as in solution) until the collision cell, and proton transfers occurred during CID as a result of the internal energy increase. In the second hypothesis, proton transfers occurred during the ESI process and the interactions between phosphate groups and amines became hydrogen bonds between neutral groups in the gas phase $\left(\mathrm{R}_{2}-\mathrm{NH}: \cdots: \mathrm{:HOPO} \mathrm{H}_{2}\right)$. Considering the large difference between the gas-phase acidity of phosphoric acid $\left(\Delta \mathrm{H}_{\text {acid }}=1387 \pm 17 \mathrm{~kJ} \mathrm{~mol}^{-1}\right.$ for the dimethyl phosphoricâacidẫ 35])ânndâtheâgas-phaseâprotonâffinityâof the amine (PA $=962 \mathrm{~kJ} \mathrm{~mol}^{-1}$ for $n$-propyl-1-propanamineấ[36]),âtheâsecondâhypothesisâisâtheâpreferredâone.

Theâbreakdownâgraphâofâ $(\text { Oligo }+\mathrm{sp})^{4-\hat{a}}($ Figureâ5a $)$ showed that, at low energies, the separation of the two components into $\mathrm{Oligo}^{4-}$ and neutral spermine occurred without any fragmentation of covalent bonds. Oligonucleotide fragments were observed only at high energies during which a large amount of the complex is dissociated. The nature and the relative abundances of these oligonucleotide fragments (checked at $100 \mathrm{eV}$; data not shown) were very similar to those of ions produced by CID of fourfold-charged free Oligo at the lowest translational energy: intact phosphodiester backbones lost a neutral nucleobase and $\mathrm{a}-\mathrm{B} / \mathrm{w}$ ions covered the entire sequence. These fragment ions were most likely produced from free Oligo after the separation of the two components. This dissociation pathway will be namedâPathâlâ(seeâFigureấ).

CID spectra of $(\mathrm{Oligo}+\mathrm{sp})^{5-}$ were not recorded because the precursor ion was not sufficiently intense. A comparison of breakdown graphs from the threefoldandâtheâfourfold-chargedâcomplexesâ(Figureấaâandâb) indicates that dissociation pathways and energies required to dissociate the complex were very similar. Thus, the charge state seems to have no significant influence on the dissociation of the $(\mathrm{Oligo}+\mathrm{sp})$ complex.

Penta-L-lysine. In the CID spectrum of $(\mathrm{Oligo}+\mathrm{K} 5)^{4-}$ recordedâatâl 00âeVâtranslationalânergyâ̂(Figureâtb),âthe main ions $\left(\mathrm{Oligo}^{3-}\right.$ and $\mathrm{K}^{-}$) were also produced by dissociation of noncovalent bonds. Like spermine, basic sites of $\mathrm{K} 5$ were protonated within the complex in solution, so protons were transferred from peptide basic sites to oligonucleotide phosphates in the same manner. The major difference is that $\mathrm{K} 5$ was lost as a singly charged ion, whereas spermine was lost as a neutral compound. This indicated that, within the $(\mathrm{Oligo}+\mathrm{K} 5)^{4-}$ complex, before separation of the components, one of the four charges was borne by the terminal carboxylic acid of the peptide, whereas the three others were located on the oligonucleotide. Because spermine has no acidic site, all charges were located on Oligo in (Oligo $+\mathrm{sp})$. The breakdown graph ofâa(Oligo $+\mathrm{K} 5)^{4-\hat{q}}$ (Figureẩd) क̂̀nowsâthatôligonucleotide fragments were produced at energies for which the dissociation of the complex into $\mathrm{K}^{-}$and $\mathrm{Oligo}^{3-}$ also occurred. The nature and the relative abundances of these oligonucleotide fragments (checked at $100 \mathrm{eV}$; data not shown) are identical to those of ions produced by CID of threefold-charged free Oligo at the lowest energyâ(Figureâ3a).âThereforeâOligoâfragmentsâwere most likely produced from free oligonucleotide after the noncovalent dissociation. Like $(\mathrm{Oligo}+\mathrm{sp})^{4-}$, the dissociation pathway can be schematized by Path I (Figureấ6).

Whereas the dissociation pathway of the fivefoldchargedâcomplexâ(Figureâ5c)âisâqualitativelyâsimilarâto that of the fourfold-charged one, $(\mathrm{Oligo}+\mathrm{K} 5)^{3-}$ exhibits 
(a)

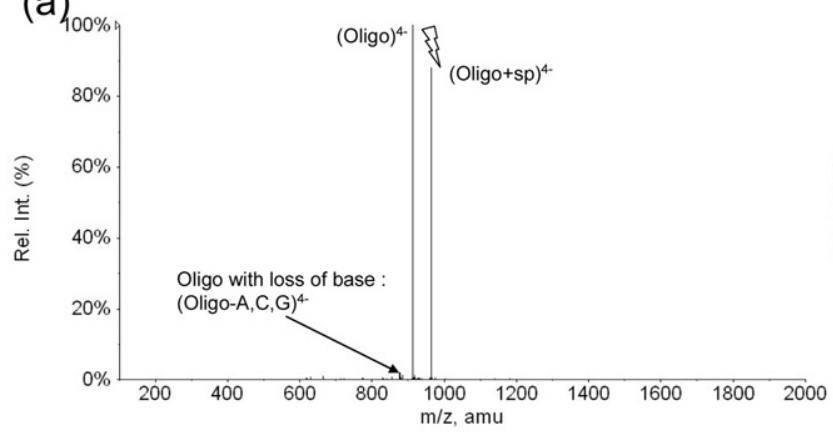

(c)

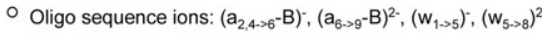

- Oligo internal sequence ions $\left(a_{m}-w_{n}\right)$

- Oligo with loss of base : (DNA-A,C,G) $)^{3}$

\& $\mathrm{K} 5$ non-covalently bound to Oligo sequence ions: $\left(\mathrm{a}_{7 \rightarrow-9}-\mathrm{B}+\mathrm{K} 5\right)^{2-},\left(\mathrm{a}_{11}-\mathrm{B}+\mathrm{K} 5\right)^{3}$, $\left(\mathrm{w}_{6->8}+\mathrm{K} 5\right)^{2 ;},\left(\mathrm{w}_{10.11}+\mathrm{K} 5\right)^{3 .}$

$\star$ K5 non-covalently bound to Oligo with loss of base: (Oligo-A,C, G+K5) ${ }^{3-}$

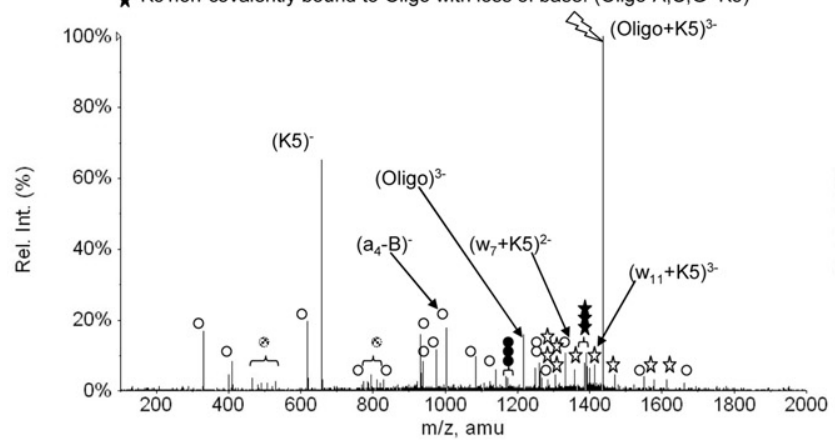

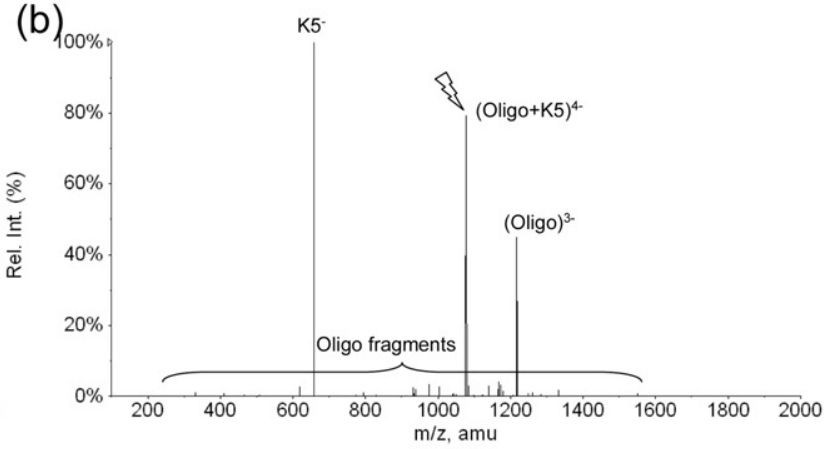

(d)

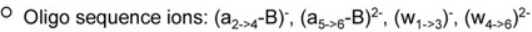

- Oligo internal sequence ions $\left(a_{m}-w_{n}\right)$

- Oligo with loss of base : (Oligo-A,C,G)

is $R 5$ non-covalently bound to Oligo sequence ions: $\left(a_{9,10}-B+R 5\right)^{3}$,

$\left(w_{6,7}+R 5\right)^{2} ;\left(w_{8}+R 5\right)^{3} ;,\left(w_{11}+R 5\right)^{4}$

$\star$ R5 non-covalently bound to Oligo with loss of base: (Oligo-A,C, G+R5) ${ }^{3-}$

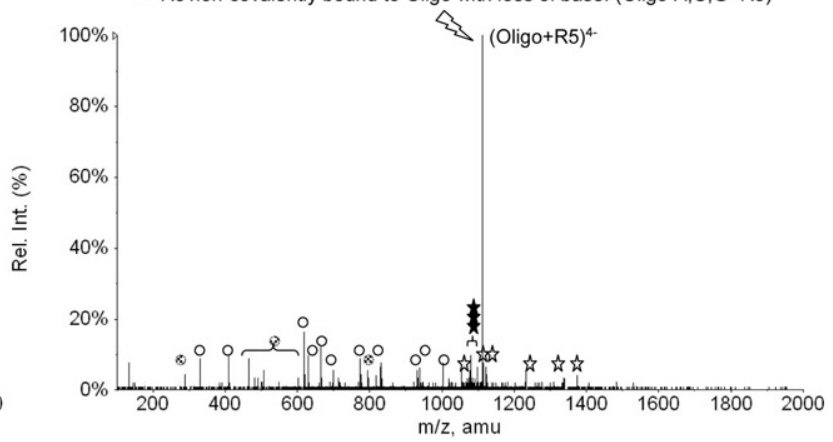

Figure 4. nanoES-CID spectra of (a) $(\text { Oligo }+ \text { spermine })^{4-}, \quad(b)(\text { Oligo }+ \text { penta-L-lysine })^{4-}$, (c) $(\text { Oligo }+ \text { penta-L-lysine })^{3-}$, (d) $(\text { Oligo+ penta-L-arginine })^{4-}$. Translational energies $[(a) 60 \mathrm{eV}$, (b) 100 $\mathrm{eV}),($ c) $135 \mathrm{eV}$, (d) $150 \mathrm{eV}$ ] are those for which the complex represents roughly $50 \%$ of the total ion current.

veryâdifferentâCIDâbehavior.âFigureâ4câshowsâaâCID spectrum recorded with a $135 \mathrm{eV}$ translational energy. In this spectrum, product ions were numerous. The presence of Oligo ${ }^{3-}$ indicated a dissociation pathway in which the neutral $\mathrm{K} 5$ was lost (noncovalent dissociation,âPathâI,âFigureâ6).âTheâpresenceâofâK5 ${ }^{-\hat{a}}$ andâthe absence of its complementary product ion $\mathrm{Oligo}^{2-}$ (expected at $m / z$ 1825) suggested a second dissociation pathway. $\mathrm{K} 5^{-}$would not be produced directly from the complex (ruling out Path I), but rather would result from a secondary dissociation, explaining the absence of intact $\mathrm{Oligo}^{2-}$. Indeed, some Oligo a-B and $\mathrm{w}$ fragment ions are present. These ions are singly or twofoldcharged and globally lighter than those, covering the entire sequence, produced by CID of free $\mathrm{Oligo}^{3-}$ at lowestâenergyâ(compareâhistogramsâinâFigureâ7câand Figureâ3a).âThisâsuggestedâthatâatâleastâaâpartâofâthese Oligo fragments were not produced from free oligonucleotide. Moreover, Oligo fragments bound to K5 were observed as two- and threefold-charged ions. Some of them are intact phosphodiester backbones having lost a nucleobase. The other ones are relatively heavy a-B and $\mathrm{w}$ fragments [the most abundant are $\left(\mathrm{w}_{7}+\mathrm{K} 5\right)^{2-}$ and $\left.\left(\mathrm{w}_{11}+\mathrm{K} 5\right)^{3-}\right]$. The observation of light free oligonucleotide fragments and heavy oligonucleotide fragments bound to $\mathrm{K} 5$ clearly indicated that fragmentation of oligonucleotide covalent bonds occurred directly from the complex. It seems that penta-L-lysine protects from CID the part of Oligo to which it is bound. Note that no K5 fragments were observed, indicating that K5 would also be fully protected by Oligo (which is longer than K5).ãTheabreakdownâgraphâofẫ(Oligo $+\mathrm{K} 5)^{3-\hat{a}}$ (Figureâ̄e) shows that cleavage of covalent bonds within the complex (leading to free and bound oligonucleotide fragments) occurred at energies for which free $\mathrm{K}^{-}$was not yet observed. Cleavage of noncovalent bonds leading to the production of $\mathrm{K}^{-}$resulted from the complex having previously undergone covalent fragmentations. This dissociation pathway will be named Path II (see Figureấ6).âltâcanâalsoâoccurâforâaâcomplexâinâwhichâK5 bears no charge. In this case, free $\mathrm{K} 5$ cannot be detected. Briefly, we can distinguish at least two kinds of dissociation pathway for $(\mathrm{Oligo}+\mathrm{K} 5)^{3-}$ : noncovalent separationâofâtheâ twoâcomponentsâ(Figureâ6,âPathâI)âand fragmentation of Oligo covalent bonds within the complex followed by the loss of neutral or singly charged K5â(Figureâ6,âPathâII).âBecauseâonlyâaâsmallâamountâof free Oligo was observed, Path I seems to be the minor one. Moreover, it must be noted that Oligo fragments produced by CID of $(\mathrm{Oligo}+\mathrm{K} 5)^{3-}$ at $75 \mathrm{eV}$ are even 


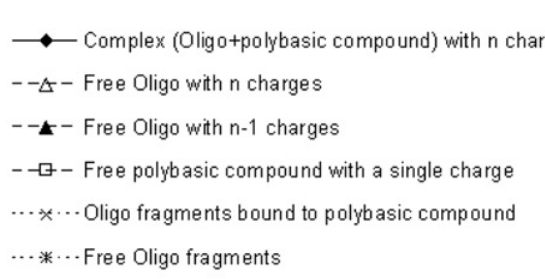

(a)
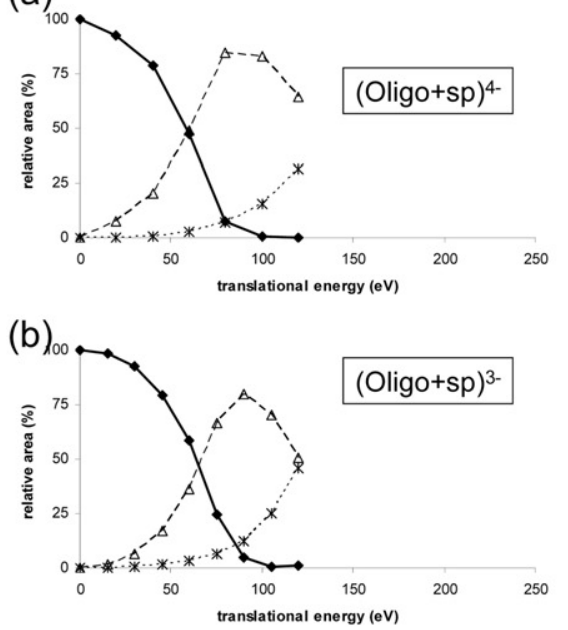
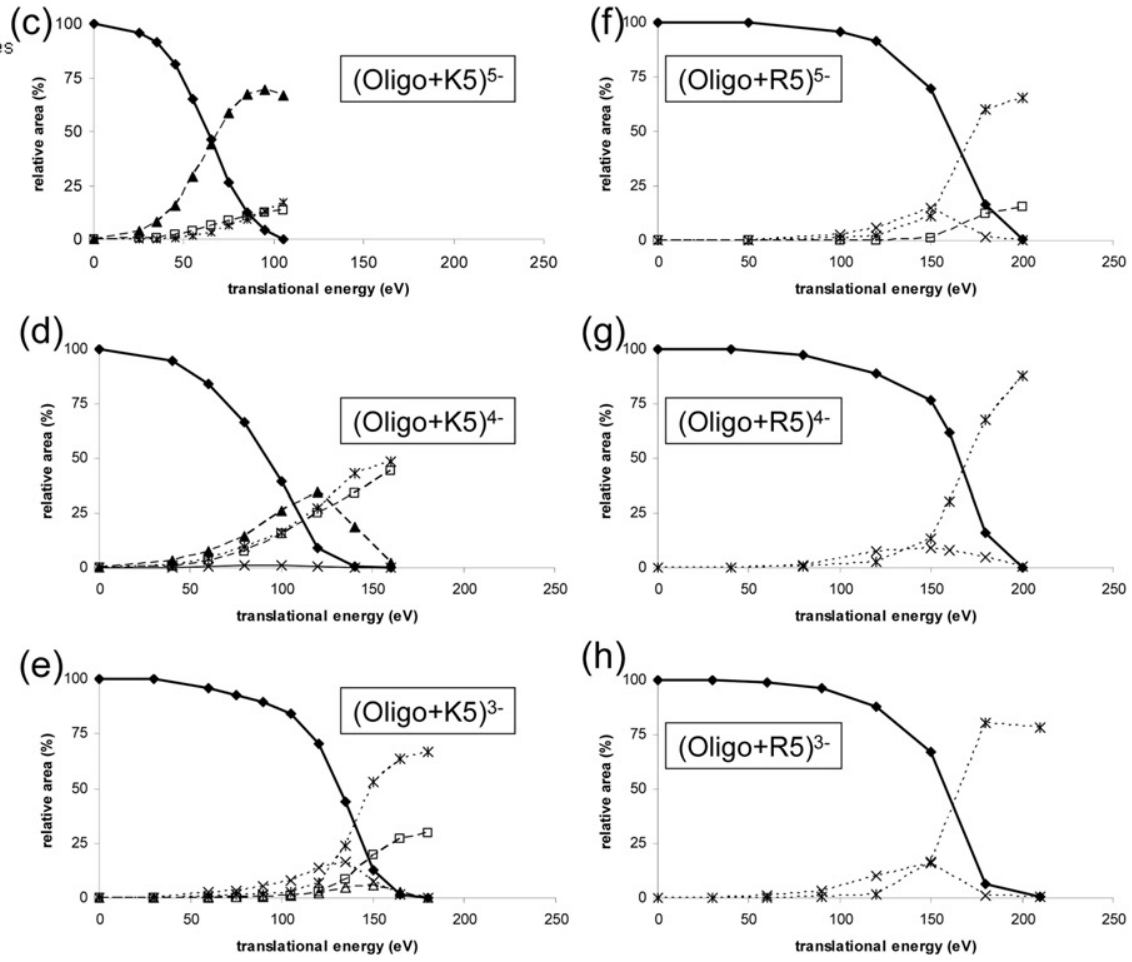

Figure 5. Breakdown graphs of (Oligo +spermine) with (a) 4 charges, (b) 3 charges, (Oligo + pentaL-lysine) with (c) 5 charges, (d) 4 charges, (e) 3 charges, (Oligo+penta-L-arginine) with (f) 5 charges, (g) 4 charges, (h) 3 charges. Nonassigned product ions represent a maximum of $5 \%$ of the total ion current of each spectrum for (a), (b), (c), (d), and (e), and 20\% for (f), (g), and (h). Most of nonassigned ions are Oligo fragment ions other than a-B or w. Declustering Potential is $40 \mathrm{~V}$ except for (c) in which it is $30 \mathrm{~V}$.

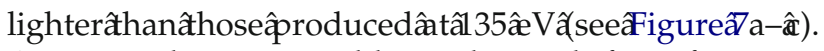
At $75 \mathrm{eV}$, the ions would mainly result from fragmentation of covalent bonds within the complex, whereas the fragments observed at $135 \mathrm{eV}$ would result from fragmentation of both complex and free Oligo.

Unlike (Oligo $+\mathrm{sp})$, the CID behavior of $(\mathrm{Oligo}+\mathrm{K} 5)$ depends on the initial charge state of the complex. Although a lower charge state favors fragmentation of oligonucleotide covalent bonds within the complex, a higher charge state favors the separation of the two components by cleavage of noncovalent interactions. It is assumed that coulomb repulsions between the oligonucleotide and the polybasic compound can play an important role. In $(\mathrm{Oligo}+\mathrm{K} 5)^{5-}$ or $4-$ CID spectra, the main product ions were Oligo ${ }^{4 \text { or } 3-}$ and $\mathrm{K}^{-}{ }^{-}$, indicating that one negative charge was located on the K5 carboxylic acid and the other negative charges were located on Oligo before separation of the components. In this case, coulomb repulsions between the peptide charge and the oligonucleotide charges can facilitate the separation of the two components. Within threefold-charged complexes, simultaneous observations of $\mathrm{K}^{-}$and $\mathrm{Oligo}^{3-}$ indicated that the three charges can be distributed in two ways: two on Oligo and one on $\mathrm{K} 5$, or three on Oligo. In the former case, coulomb repulsion was less powerful than with $(\mathrm{Oligo}+\mathrm{K} 5)^{5-}$ or $4-$ because fewer charges were in- volved. In the latter case, no coulomb repulsion occurred between the two components. For both charge distributions, separation of the two components was less facilitated than with five- or fourfoldcharged complex, and fragmentation of oligonucleotide covalent bonds within the complex became a competitive pathway. Separation of the two components is thus observed in a smaller amount and at higher energies. Because the separation of the two components into Oligo ${ }^{2-}$ and $\mathrm{K}^{-}$is not observed while the separation into Oligo ${ }^{3-}$ and neutral $\mathrm{K} 5$ is observed, it is supposed that most of the complex has its three charges located on the oligonucleotide.

Despite a lower acidity of carboxylic acid compared to phosphoric acid in both solution and gas phase $\left(\Delta \mathrm{H}_{\text {acid }}=\right.$ â1456â $\pm \hat{a} 9 \mathrm{~kJ} \mathrm{~mol}^{-1}$ â forâtheâaceticâacidâ[37], $\Delta \mathrm{H}_{\text {acid }}=1387 \pm 17 \mathrm{~kJ} \mathrm{~mol}^{-1}$ for the dimethyl phosphoricâacidâ[35]),âK5âalwaysâbearâaâchargeâwithinâtheâfourand fivefold-charged complexes. This can be explained if we assume that six phosphates are bound to the peptideâlysineâresiduesâandâterminalâamineâa 38].ânnâthis case, only five free acidic sites remain that are available to bear a charge. It can be expected that the more numerous the charges, the more probable the location of a charge on the carboxylic acid to minimize coulomb repulsion on the oligonucleotide backbone.

Such a charge state dependency is not observed with 

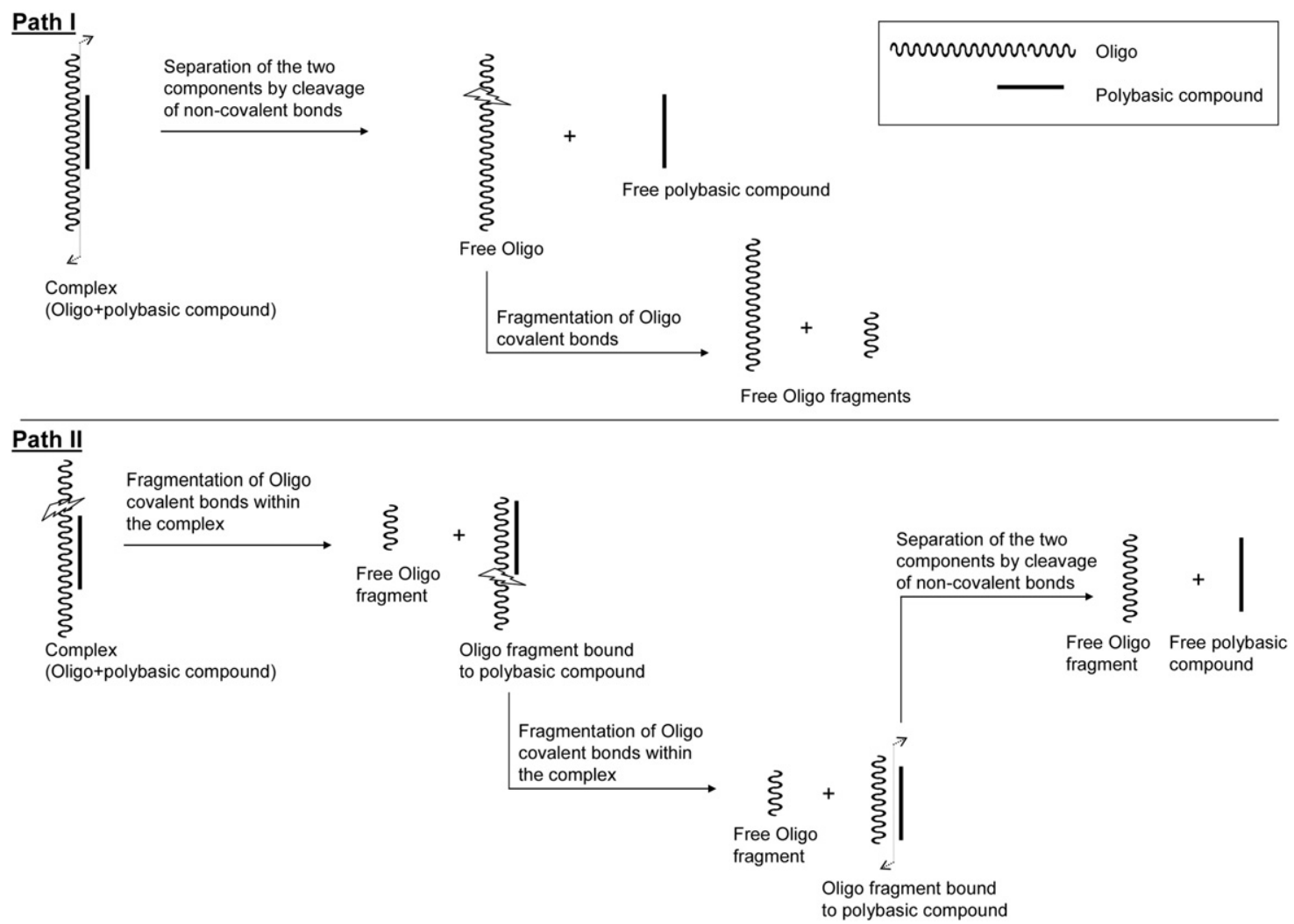

Figure 6. Schematic representation of the two kinds of dissociation pathway. Path I: separation of Oligo and polybasic compound by cleavage of noncovalent bonds (followed by fragmentation of free Oligo). Path II: fragmentation of Oligo covalent bonds within the complex (followed by separation of Oligo and polybasic compound).

$($ Oligo + sp), given that no charge can be located on the polyamine.

Penta-L-arginine. FigureâtdâdisplaysâtheâCIDâspectrum of $(\mathrm{Oligo}+\mathrm{R} 5)^{4-}$ recorded at $150 \mathrm{eV}$ translational energy. Numerous product ions were observed. These ions were light free oligonucleotide fragments and heavy oligonucleotide fragments bound to R5, suggesting that fragmentations of oligonucleotide covalent bonds occurred within the complex. The breakdown graphâofâ(Oligo $+\mathrm{R} 5)^{4-\hat{a}}$ (Figureâ5g)âconfirmsâthatâthe complex disappeared on cleavage of covalent bonds and no free R5 or fragment was observed. This indicated that R5 bears no charge within the complex, which can be explained by an intramolecular bond with an arginine residue, as seen above. It was produced as a neutral species from complexes having first undergone fragmentation of oligonucleotide covalent bonds. Moreover, no free oligonucleotide was observed, ruling out the hypothesis of a competitive separation of the two intact components by cleavage of noncovalent bonds.âThus,âinâthisâcase,âPathâllâa(Figureấ)âisâtheâmain dissociation pathway. (Oligo $+\mathrm{R} 5)^{3-}$ and (Oligo $\left.+\mathrm{R} 5\right)^{5-}$ have a dissociation pathway very similar to that of $(\mathrm{Oligo}+\mathrm{R} 5)^{4-\hat{a}}$ (seeâFigureâbfâandâh), âexceptâtheâappearance of $\mathrm{R}^{-}$at high translational energies for $(\mathrm{Oligo}+\mathrm{R} 5)^{5-}$, indicating that, in this case, R5 can bear one charge within the complex. This behavior, on the whole independent of the charge state, can be attributed to a great stability of phosphate group-arginine basic site bonds. Indeed, the bidentate nature of this interactionâpossiblyâmakesâtheâbondâstrongerâ[39].âMoreover, the proton affinity of arginine is greater than that of lysine (respectively, 1051 and $996 \mathrm{~kJ} \mathrm{~mol}^{-1}$ for the single aminoâacidsâ[36]).âThereforeâtheâprotonâtransfersâfrom the protonated basic sites to the oligonucleotide is less favored, making the loss of the polypeptide more difficult. Finally, the absence of charge on R5 in most cases renders insignificant the coulomb repulsion between oligonucleotide and peptide. As a result of these effects, coulomb repulsions would not be sufficient to overcome the strong Oligo-R5 interactions and the only pathway is the covalent fragmentation of the complex before cleavage of noncovalent bonds, irrespective of the charge state.

No comparison of energies required to dissociate $(\mathrm{Oligo}+\mathrm{sp})$, (Oligo $+\mathrm{K} 5)$, and (Oligo $+\mathrm{R} 5)$ can be made. Indeed, the three complexes have different sizes and waysâofâdissociationâ[40,â41].âMoreover,âitâhasâbeen shown that the in-solution interactions could be modified in the gas phase by multiple proton transfers. In this process, proton affinities can play a major role. A dependency of the dissociation pathway on the proton affinity was previously demonstrated by Gabelica et al. 

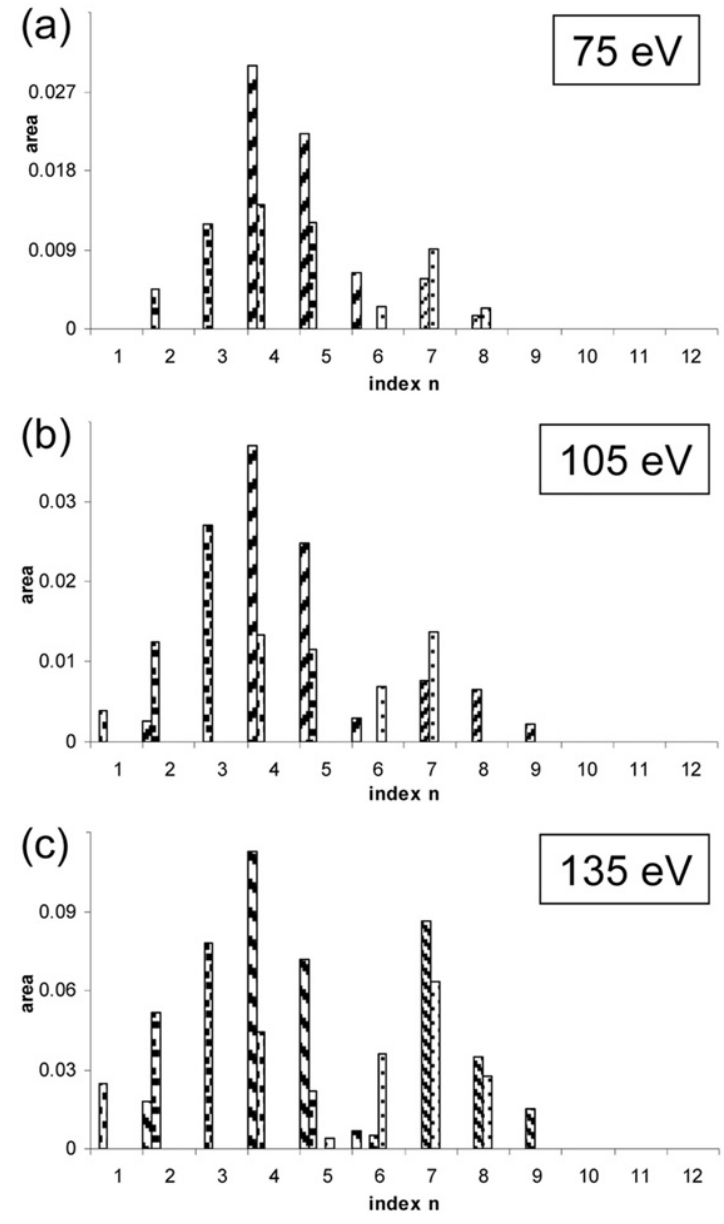

$$
\begin{array}{ll}
\text { घan-B with } 1 \text { charge } & \text { ar } w_{n} \text { with } 1 \text { charge } \\
\square a_{n}-B \text { with } 2 \text { charges } & \quad \text { o } w_{n} \text { with } 2 \text { charges }
\end{array}
$$

Figure 7. Abundances of the free $\mathrm{a}-\mathrm{B} / \mathrm{w}$ ions produced by $\mathrm{CID}$ of $(\mathrm{Oligo}+\mathrm{K} 5)^{3-}$ as a function of their length and charge state. Translational energy is $75 \mathrm{eV}$ (a), $105 \mathrm{eV}$ (b), $135 \mathrm{eV}$ (c). Internal fragments are not shown.

[42]âinâtheâcaseâofâduplex-甩rugâcomplexes.âFurthermore, the dissociation pathway could be partly influenced by coulomb repulsions. However, differences in CID patterns between $(\mathrm{Oligo}+\mathrm{sp})$ (noncovalent dissociation) and $(\mathrm{Oligo}+\mathrm{R})$ (covalent fragmentation within the complex) are not dependent on charge state. Although proton affinities can play a role, the difference can be partly attributable to a weaker interaction within $(\mathrm{Oligo}+\mathrm{sp})$ than within $(\mathrm{Oligo}+\mathrm{R} 5)$. Indeed, spermine can interact with the oligonucleotide by only four protonated amines, whereas binding sites of poly-Larginine are greater in number and, most important, more powerful. On the other hand, CID behavior of $($ Oligo $+\mathrm{K} 5)$ is clearly charge-state dependent. At a higher charge state, coulomb repulsions seem to have a greater importance and lead to separation of the two components, whereas low-charged complexes mainly undergo fragmentation of the oligonucleotide covalent bonds. To probe the contribution of these repulsions and to assess the potentiality of dissociation spectra to provide information about structure and stability, MS/MS experiments were carried out with complexes involving poly-L-lysines with various lengths.

\section{Tandem Mass Spectrometry: Influence of Length of the Polybasic Compound and Charge State}

Ideally, poly-L-lysine is expected to occupy as many adjacent oligonucleotide phosphates as it has protonatedäbasicâsitesẫ [38]. âConsequently, âtheâlongerâtheâpolyL-lysine, the more numerous the intermolecular bonds and the stronger the interaction must be.

Noncovalent dissociation. Because sufficiently intense complexes between the oligonucleotide and polydisperseâpoly-L-lysineâwereâobservedâ(Figureâld),âdissociation curves were built with complexes involving Oligo and poly-L-lysine of various lengths. These experiments were first carried out in conditions favoring dissociationâ ofâ noncovalentâ interactionsâ (Pathâ I,â Figureâ 6), i.e., with complexes bearing four negative charges. $(\mathrm{Oligo}+\mathrm{K} 4)^{4-},(\mathrm{Oligo}+\mathrm{K} 5)^{4-}$, and $(\mathrm{Oligo}+\mathrm{K} 6)^{4-}$ were submitted to CID experiments (data not shown). The dissociation curve of $(\mathrm{Oligo}+\mathrm{K} 5)^{4-}$ is very similar to thatâdrawnâwithâmonodisperseâpenta-L-lysineâ(Figure $5 \mathrm{~d})$.â Inâ theâ sameâ manner,â $(\mathrm{Oligo}+\mathrm{K} 4)^{4-\hat{a}}$ and $(\mathrm{Oligo}+\mathrm{K} 6)^{4-}$ dissociate into Oligo ${ }^{3-}$ and $\mathrm{KX}^{-}$. Energies required to dissociate half of the complex are 96 , 104 , and $112 \mathrm{eV}$, respectively. Because the three complexes have different sizes and perhaps different collision cross sections, these energies are not directly comparable. However, they seem to be very close to each other. It seems that, in this case, the separation of the two components is driven by coulomb repulsions and is not representative of the intrinsic stability of the complex.

Fragmentation of covalent bonds. CID experiments were also carried out under conditions favoring the fragmentation of covalent bonds, i.e., with threefold-charged complexes.âFigureâ8a-âlâdepictâdissociationâcurvesâof respectively $(\mathrm{Oligo}+\mathrm{K} 4)^{3-}, \quad(\mathrm{Oligo}+\mathrm{K} 5)^{3-}, \quad(\mathrm{Oligo}+$ $\mathrm{K} 6)^{3-}$, and $(\mathrm{Oligo}+\mathrm{K} 7)^{3-}$. The dissociation curve of $(\mathrm{Oligo}+\mathrm{K} 5)^{3-}$ obtained with $\mathrm{K} 5$ coming from poly-Llysineâ(Figureâ8b)âisâidenticalâtoâthatâofâ(Oligo $+\mathrm{K} 5)^{3-}$ obtainedâwithâmonodisperseâpenta-L-lysineâ(Figureâ5e): fragmentations of oligonucleotide covalent bonds within the complex followed by the loss of neutral or charged K5 (Pathâll,âFigureấ)âconstituteâtheâmajorâpathway,âwhereas the separation into neutral $\mathrm{K} 5$ and Oligo ${ }^{3-}$ (Path I) constitutes the minor one. A comparison of the four breakdownâgraphsâ(Figureâ8a-̂̂l)âconfirmsâaâdecreaseâofâthe Oligo $^{3-}$ production and an increase of $\mathrm{KX}^{-}$production with increasing poly-L-lysine length. This means that the amount of the noncovalent dissociation decreases with increasing size of poly-L-lysine, which can be explained by a greater stability of the complexes involving the longer 

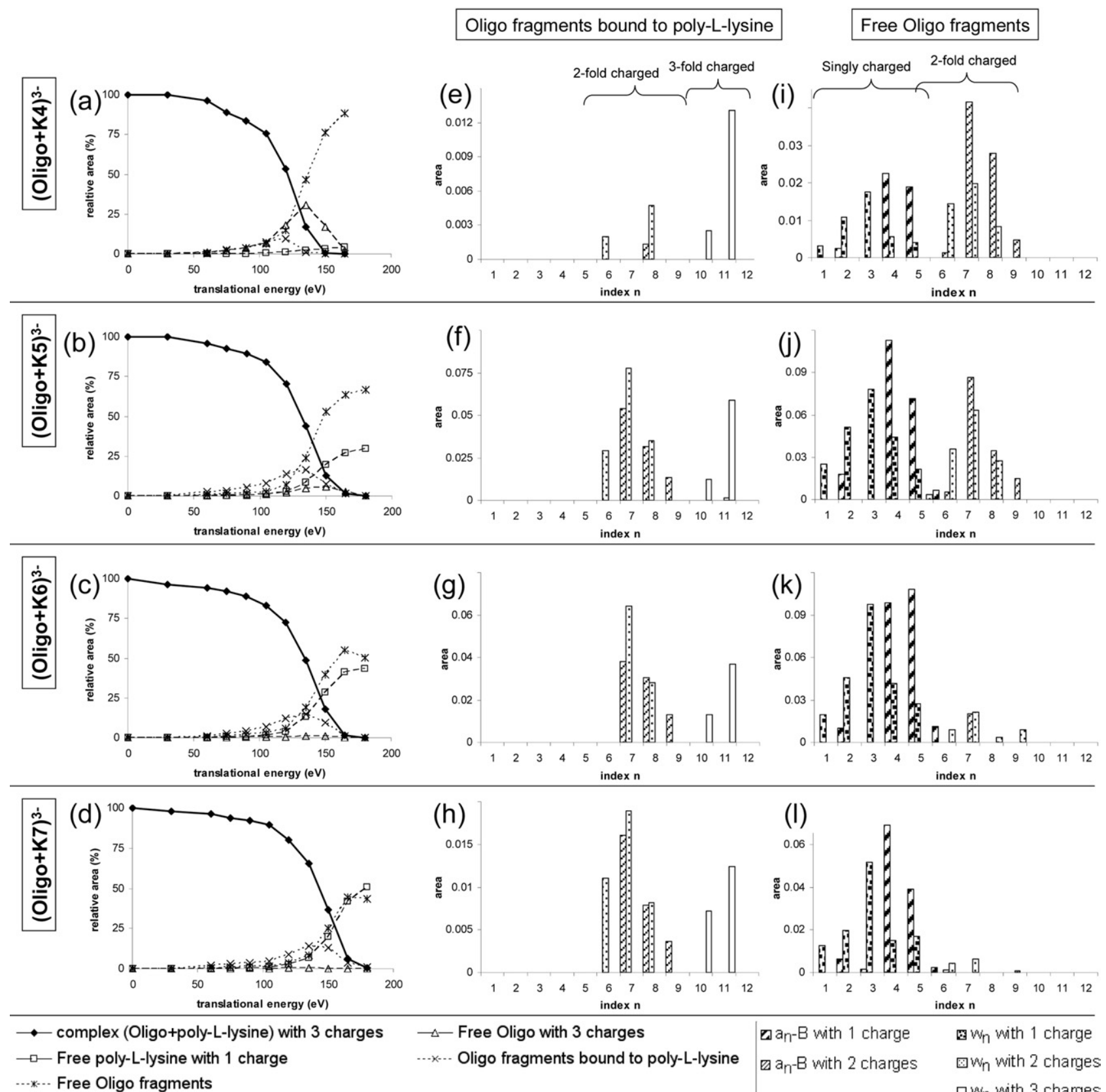

$-\Delta$ Free Oligo with 3 charges
$\ldots . .$. Oligo fragments bound to poly-L-lysine

\begin{tabular}{|c|c|}
\hline שan-B with 1 charge & 国 $W_{n}$ with 1 charge \\
\hline van-B with 2 charges & ⿴囗大 $W_{n}$ with 2 charges \\
\hline
\end{tabular}

Figure 8. Breakdown graphs (first column), areas of Oligo a-B/w fragments bound to poly-L-lysine as a function of their length and charge state (second column), and areas of free Oligo a-B/w fragments as a function of their length and charge state (third column) for (Oligo $+\mathrm{K} 4)^{3-}[(\mathbf{a})$, (e), and (i) ], $(\mathrm{Oligo}+\mathrm{K} 5)^{3-}\left[(\mathbf{b}),(\mathbf{f})\right.$, and (j)], $(\mathrm{Oligo}+\mathrm{K} 6)^{3-}[(\mathbf{c}),(\mathbf{g})$, and $(\mathbf{k})],(\mathrm{Oligo}+\mathrm{K} 7)^{3-}[(\mathbf{d}),(\mathbf{h})$, and (l)]. Breakdown graphs: nonassigned product ions represent a maximum of $6 \%$ of the total ion current. Histograms: translational energy is $120 \mathrm{eV}$ for $(\mathbf{e})$ and $(\mathbf{i})$; $135 \mathrm{eV}$ for $(\mathbf{f}),(\mathbf{j}),(\mathbf{g})$, and $(\mathbf{k})$; $150 \mathrm{eV}$ for $(\mathbf{h})$ and (1).

poly-L-lysines. Furthermore, the decrease of the Oligo ${ }^{3-}$ production and the increase of the $\mathrm{KX}^{-}$production when increasing poly-L-lysine length can indicate that the longer the poly-L-lysine, the more probable is the presence of a charge on its carboxylic acid within the complex. This can be explained by the fact that the longer the poly-Llysine, the less numerous the unbound phosphates available to bear a charge. Interestingly, despite a less powerful coulomb repulsion in the case of $(\mathrm{Oligo}+\mathrm{K} 4)^{3-}$ (because $\mathrm{K} 4$ can bear no charge), dissociation of noncovalent bonds occurred, indicating a relatively weak interaction. Conversely, complexes with longer poly-L-lysine underwent fragmentation of covalent bonds rather than separation of the two components, demonstrating that the noncovalent interaction is strong enough to surpass coulomb repulsion. As supposed earlier, in the case of threefold-charged 
complexes, coulomb repulsions do not seem to play a major role.

The nature of the Oligo a-B/w fragments bound to poly-L-lysine (produced by Path II) was accurately assigned for each of the four threefold-charged complexes.âFigureâ8e-đhârepresentâtheirâabundanceâasâa function of their length and charge state. These histograms are given at the translational energy for which the area of the precursor ion peak is roughly $50 \%$ of the total ion current. Except in the case of (Oligo $+\mathrm{K} 4)$, for which these fragments were not sufficiently intense to be representative, no difference in the length of Oligo fragments was observed as a function of poly-L-lysine size. In each case, the same $a-B$ and $w$ fragments including 6 to 11 nucleotidic units bound to the polybasic compound were detected. In the same way, comparison of spectra recorded at $75 \mathrm{eV}$ (not shown) showed no difference in the length of bound fragments. This was surprising because it could be expected that the longer the poly-L-lysine, the longer the part of DNA bound to it. From this experiment, it seems that a longer poly-L-lysine does not protect a longer part of DNA from CID. Moreover, relative areas of a-B and w Oligo fragments were similar to those of the heaviest fragmentsâproducedâfromâfreeâOligoâ(Figureẩa).âTherefore no specific binding site can be determined, as expected.

At a translational energy for which the area of the precursor ion is roughly $50 \%$ of the total ion current, examination of the length of free Oligo fragments as a functionâofâtheâpoly-L-lysineâsizeâ(Figureâ8i-1)âshowed that the longer the poly-L-lysine, the shorter the fragments. Indeed, when increasing the poly-L-lysine size, the amount of twofold-charged fragments (which are heavier than the singly charged ones) decreases. As seen above, this is not because a longer poly-L-lysine protects a longer segment of the oligonucleotide from CID. As discussed earlier in the case of monodisperse penta-L-lysine, a part of the a-B/w fragments can come from fragmentation of free Oligo (Path I), whereas the others come from fragmentation of covalent bonds within the complex (Path II). Fragments coming from Path I are heavier than those resulting from Path II. Therefore the decrease of the length of Oligo fragments when increasing the poly-L-lysine size could be explained by a decrease of the proportion of Path I compared to that of Path II. Comparison of fragments coming from Path II only can be made by checking them at $75 \mathrm{eV}$ (not shown) for (Oligo+K5), (Oligo+K6), and (Oligo $+\mathrm{K} 7)$. At this translational energy, Path $\mathrm{I}$ is negligible even for (Oligo $+\mathrm{K} 5)$, as indicated by the presence of a very small amount of $\mathrm{Oligo}^{3-}$. The three histograms were roughly complementary with those in Figureâ8f-đhâandâshowedânoâobviousâdifferences.âThis confirmed that no difference of fragment size coming from Path II can be observed in the range of poly-Llysine length that was studied. So it is not possible to affirm that the polybasic compound covers a length of Oligo proportional to its size. However, as discussed above, the decrease of the proportion of Path I when increasing the length of poly-L-lysine can indicate a greater stability when a longer polybasic compound is involved.

\section{Conclusion}

The results presented in this work showed that DNA oligonucleotide-polybasic compound complexes can be observed by nanoES-MS. In solution, the components of these complexes are primarily held together by ionic bonds. The absence of arginine in some polybasic compounds and the polydispersity of one of them make this study original. In this context, mass spectrometry allows separation of complexes that differ by their stoichiometry and the length of the polybasic compound, a unique feature of this method. Tandem mass spectrometry experiments were carried out to better understand the interactions involved in these complexes. It was shown that the nature of the interactions can be different in solution and in the gas phase arising from multiple proton transfers. Several fragmentation pathways can (co)exist according to the nature of the polybasic compound and the charge state of the complex. When the dissociation was not driven by coulomb repulsions (cases of spermine and penta-L-arginine), the nature of the dissociation pathway can be partly related to the strength of the interaction, even if proton transfers and size differences make a comparison of the various systems difficult. When poly-L-lysine was involved, high charge state complexes underwent noncovalent dissociation, essentially driven by coulomb repulsions, preventing the observation of differences in stability according to the length of the polybasic compound. However, for the less-charged complexes, CID experiments enabled us to observe interesting differences that can be related to stability of the complexes. We hope that this work opens the way to the study of complexes involving DNA and polydisperse polymers.

\section{Acknowledgments}

Financial support from the Association Française contre les Myopathies (AFM) is gratefully acknowledged.

\section{References}

1. Hansen, J. C. Conformational Dynamics of the Chromatin Fiber in Solution: Determinants, Mechanisms, and Functions. Annu. Rev. Biophys. Biomol. Struct. 2002, 31, 361-392.

2. Bachrach, U. Naturally Occurring Polyamines: Interaction with Macromolecules. Curr. Protein. Pept. Sci. 2005, 6, 559-566.

3. Chirila, T. V.; Rakoczy, P. E.; Garrett, K. L.; Lou, X.; Constable, I. J. The Use of Synthetic Polymers for Delivery of Therapeutic Antisense Oligodeoxynucleotides. Biomaterials 2002, 23, 321-342.

4. Zhang, S.; Xu, Y.; Wang, B.; Qiao, W.; Liu, D.; Li, Z. Cationic Compounds Used in Lipoplexes and Polyplexes for Gene Delivery. J. Controlled Release 2004, 100, 165-180.

5. Yamashita, M.; Fenn, J. B. Electrospray Ion Source. Another Variation on the Free-Jet Theme. J. Phys. Chem. 1984, 88, 4451-4459.

6. Tanaka, K.; Waki, H.; Ido, Y.; Akita, S.; Yoshida, T. Protein and Polymer Analyse up to $m / z 100,000$ by Laser Ionization Time-of-Flight Mass Spectrometry. Rapid Commun. Mass Spectrom. 1988, 2, 151-153.

7. Karas, M.; Hillenkamp, F. Laser Desorption Ionization of Proteins with Molecular Masses Exceeding 10,000 Daltons. Anal. Chem. 1988, 60, 2299-2301. 
8. Loo, J. A. Studying Noncovalent Protein Complexes by Electrospray Ionization Mass Spectrometry. Mass Spectrom. Rev. 1997, 16, 1-23.

9. Hofstadler, S. A.; Griffey, R. H. Analysis of Noncovalent Complexes of DNA and RNA by Mass Spectrometry. Chem. Rev. 2001, 101, 377-390.

10. Daniel, J. M.; Friess, S. D.; Rajagopalan, S.; Wendt, S.; Zenobi, R. Quantitative Determination of Noncovalent Binding Interactions Using Soft Ionization Mass Spectrometry. Int. J. Mass Spectrom. 2002, 216, 1-27.

11. Bolbach, G. Matrix-Assisted Laser Desorption/Ionization Analysis of Non-Covalent Complexes: Fundamentals and Applications. Curr. Pharm. Des. 2005, 11, 2535-2557.

12. Asara, J. M.; Allison, J. Enhanced Detection of Oligonucleotides in UV MALDI MS Using the Tetraamine Spermine as a Matrix Additive. Anal. Chem. 1999, 71, 2866-2870.

13. Vandell, V. E.; Limbach, P. A. Polyamine Co-matrices for Matrixassisted Laser Desorption/Ionization Mass Spectrometry of Oligonucleotides. Rapid Commun. Mass Spectrom. 1999, 13, 2014-2021.

14. Distler, A. M.; Allison, J. 5-Methoxysalicylic Acid and Spermine: A New Matrix for the Matrix-Assisted Laser Desorption/Ionization Mass Spectrometry Analysis of Oligonucleotides. J. Am. Soc. Mass Spectrom. 2001, 12, 456-462

15. Distler, A. M.; Allison, J. Additives for the Stabilization of DoubleStranded DNA in UV-MALDI MS. J. Am. Soc. Mass Spectrom. 2002, 13, 1129-1137.

16. Juhasz, P.; Biemann, K. Mass Spectrometric Molecular-Weight Determination of Highly Acidic Compounds of Biological Significance via their Complexes with Basic Polypeptides. Proc. Natl. Acad. Sci. 1994, 91, 4333-4337.

17. Tang, X.; Callahan, J. H.; Zhou, P.; Vertes, A. Noncovalent ProteinOligonucleotide Interactions Monitored by Matrix-Assisted Laser Desorption/Ionization Mass Spectrometry. Anal. Chem. 1995, 67, 45424548.

18. Lin, S.; Cotter, R. J.; Woods, A. S. Detection of Non-Covalent Interaction of Single and Double Stranded DNA with Peptides by MALDI-TOF. Proteins: Struct. Funct. Genet. Suppl. 1998, 2, 12-21.

19. Ohara, K.; Smietana, M.; Vasseur, J.-J. Characterization of Specific Noncovalent Complexes between Guanidinium Derivatives and SingleStranded DNA by MALDI. I. Am. Soc. Mass Spectrom. 2006, 17, 283-291.

20. Lin, S.; Long, S.; Ramirez, S. M.; Cotter, R. J.; Woods, A. S. Characterization of the "Helix Clamp" Motif of HIV-1 Reverse Transcriptase Using MALDI-TOF MS and Surface Plasmon Resonance. Anal. Chem. 2000, 72, 2635-2640.

21. Luo, S.-Z.; Li, Y.-M.; Qiang, W.; Zhao, Y.-F.; Abe, H.; Nemoto, T.; Qin, X.-R.; Nakanishi, H. Detection of Specific Noncovalent Interaction of Peptide with DNA by MALDI-TOF. J. Am. Soc. Mass Spectrom. 2004, 15, 28-31

22. Schug, K.; Lindner, W. Development of a Screening Technique for Noncovalent Complex Formation between Guanidinium- and Phosphonate-functionalized Amino Acids by Electrospray Ionization Ion Trap Mass Spectrometry: Assessing Ionization and Functional Group Interaction. Int. J. Mass Spectrom. 2004, 235, 213-222.

23. Schug, K.; Lindner, W. Using Electrospray Ionization-Mass Spectrometry/Tandem Mass Spectrometry and Small Molecules to Study Guanidinium-Anion Interactions. Int. J. Mass Spectrom. 2005, 241, 11-23.

24. Ciruela, F.; Burgueño, J.; Casado, V.; Canals, M.; Marcellino, D.; Goldberg, S. R.; Bader, M.; Fuxe, K.; Agnati, L. F.; Lluis, C.; Franco, R.; Ferré, S.; Woods, A. S. Combining Mass Spectrometry and Pull-Down Techniques for the Study of Receptor Heteromerization. Direct EpitopeEpitope Electrostatic Interactions between Adenosine $\mathrm{A}_{2 \mathrm{~A}}$ and Dopamine $\mathrm{D}_{2}$ Receptors. Anal. Chem. 2004, 76, 5354-5363.
25. Woods, A. S.; Huestis, M. A. A Study of Peptide-Peptide Interaction by Matrix-assisted Laser Desorption/Ionization. J. Am. Soc. Mass Spectrom. 2001, 12, 88-96.

26. Woods, A. S. The Mighty Arginine, the Stable Quaternary Amines, the Powerful Aromatics, and the Aggressive Phosphate: Their Role in the Noncovalent Minuet. J. Proteome Res. 2004, 3, 478-484.

27. Woods, A. S.; Ferré, S. Amazing Stability of the Arginine-Phosphate Electrostatic Interaction. J. Proteome Res. 2005, 4, 1397-1402.

28. Jackson, S. N.; Wang, H.-Y. J.; Woods, A. S. Study of the Fragmentation Patterns of the Phosphate-Arginine Noncovalent Bond. J. Proteome Res. 2005, 4, 2360-2363.

29. Jackson, S. N.; Wang, H.-Y. J.; Yergey, A.; Woods, A. S. Phosphate Stabilization of Intermolecular Interactions. J. Proteome Res. 2006, 5 $122-126$.

30. Wan, K. X.; Gross, M. L.; Shibue, T. Gas-Phase Stability of DoubleStranded Oligonucleotides and their Noncovalent Complexes with DNA-Binding Drugs as Revealed by Collisional Activation in an Ion Trap. J. Am. Soc. Mass Spectrom. 2000, 11, 450-457.

31. Gabelica, V.: De Pauw, E. Collision-induced Dissociation of 16-mer DNA Duplexes with Various Sequences: Evidence for Conservation of the Double Helix Conformation in the Gas Phase. Int. J. Mass Spectrom. 2002, 219, 151-159.

32. Keller, K. M.; Zhang, J.; Oehlers, L.; Brodbelt, J. S. Influence of Initial Charge State on Fragmentation Patterns for Noncovalent Drug/DNA Duplex Complexes. J. Mass Spectrom. 2005, 40, 1362-1371.

33. Keller, K. M.; Breeden, M. M.; Zhang, J.; Ellington, A. D.; Brodbelt, J. S. Electrospray Ionization of Nucleic Acid Aptamer/Small Molecule Complexes for Screening Aptamer Selectivity. J. Mass Spectrom. 2005, 40, 1327-1337.

34. McLuckey, S. A.; Van Berkel, G. J.; Glish, G. L. Tandem Mass Spectrometry of Small, Multiply Charged Oligonucleotides. J. Am. Soc. Mass Spectrom. 1992, 3, 60-70.

35. Lum, R. C.; Grabowski, J. J. Trimethyl Phosphate: The Intrinsic Reactivity of Carbon versus Phosphorus Sites with Anionic Nucleophiles. J. Am. Chem. Soc. 1992, 114, 8619-8627.

36. Hunter, E. P. L.; Lias, S. G. Evaluated Gas Phase Basicities and Proton Affinities of Molecules: An Update. J. Phys. Chem. Ref. Data 1998, 27, 413-656.

37. Taft, R. W.; Topsom, R. D. The Nature and Analysis of Substituent Effects. Prog. Phys. Org. Chem. 1987, 16, 1-83.

38. Zhang, W.; Bond, J. P.; Anderson, C. F.; Lohman, T. M.; Record, M. T. Jr. Large Electrostatic Differences in the Binding Thermodynamics of a Cationic Peptide to Oligomeric and Polymeric DNA. Proc. Natl. Acad. Sci. U.S.A. 1996, 93, 2511-2516.

39. Schug, K. A.; Lindner, W. Noncovalent Binding between Guanidinium and Anionic Groups: Focus on Biological- and Synthetic-Based Arginine/Guanidinium Interactions with Phosph[on]ate and Sulf[on]ate Residues. Chem. Rev. 2005, 105, 67-113.

40. Gabelica, V.; De Pauw, E. Comparison between Solution-Phase Stability and Gas-Phase Kinetic Stability of Oligodeoxynucleotide Duplexes. I. Mass Spectrom. 2001, 36, 397-402.

41. Gabelica, V.; De Pauw, E. Comparison of the Collision-Induced Dissociation of Duplex DNA at Different Collision Regimes: Evidence for a Multistep Dissociation Mechanism. J. Am. Soc. Mass Spectrom. 2002, 13 91-98.

42. Rosu, F.; Pirotte, S.; De Pauw, E.; Gabelica, V. Positive and Negative Ion Mode ESI-MS and MS/MS for Studying Drug-DNA Complexes. Int. J. Mass Spectrom. 2006, 253, 156-171. 